\title{
Clinical leadership development in postgraduate medical education and training: policy, strategy, and delivery in the UK National Health Service
}

This article was published in the following Dove Press journal:

Journal of Healthcare Leadership

17 November 2015

Number of times this article has been viewed

\section{Reena Aggarwal ${ }^{1,2}$ \\ Tim Swanwick ${ }^{2}$}

'Women's Health, Whittington Health, London, UK; ${ }^{2}$ Health Education England, North Central and East London, London, UK
Correspondence: Reena Aggarwal Women's Health, Whittington Health, Magdala Avenue, London NI9 5NF, UK Tel +447799664215

Email raggarwal73@doctors.org.uk

\begin{abstract}
Achieving high quality health care against a background of continual change, increasing demand, and shrinking financial resource is a major challenge. However, there is significant international evidence that when clinicians use their voices and values to engage with system delivery, operational efficiency and care outcomes are improved. In the UK National Health Service, the traditional divide between doctors and managers is being bridged, as clinical leadership is now foregrounded as an important organizational priority. There are 60,000 doctors in postgraduate training (junior doctors) in the UK who provide the majority of front-line patient care and form an "operating core" of most health care organizations. This group of doctors is therefore seen as an important resource in initiating, championing, and delivering improvement in the quality of patient care. This paper provides a brief overview of leadership theories and constructs that have been used to develop a raft of interventions to develop leadership capability among junior doctors. We explore some of the approaches used, including competency frameworks, talent management, shared learning, clinical fellowships, and quality improvement. A new paradigm is identified as necessary to make a difference at a local level, which moves learning and leadership away from developing "leaders", to a more inclusive model of developing relationships between individuals within organizations. This shifts the emphasis from the development of a "heroic" individual leader to a more distributed model, where organizations are "leader-ful" and not just "well led" and leadership is centered on a shared vision owned by whole teams working on the frontline.
\end{abstract}

Keywords: National Health Service, junior doctors, quality improvement, management, health care, leadership, fellowships, mentoring

\section{Introduction}

Health care has both scientific and social dimensions and is also the source of immense political concern. Vast sums of gross domestic product are spent on health, ${ }^{1}$ the organization of complex systems of health care provision is difficult, and governments are increasingly judged on their ability to deliver high value services. ${ }^{2}$ In the UK, a National Health Service (NHS) employs over 1.5 million people with a budget of around $£ 115$ billion under the supervision of its departments of health. Notwithstanding its size, the NHS appears to be an effective system. In 2014, a Commonwealth Fund report concluded that in comparison with the health care systems of ten other countries (Australia, Canada, France, Germany, the Netherlands, New Zealand, Norway, Sweden, Switzerland, and USA), the NHS was the most impressive overall, although lagging behind on health outcomes. ${ }^{3}$ By comparison, the USA has the most expensive health care system, yet ranked last in measures of health outcomes, quality, and efficiency. 
Despite the UK's high-ranking, significant shortcomings exist in the quality and availability of care, as highlighted by a recent public inquiry by Sir Robert Francis. The "Francis Report" detailed catastrophic failings in patient care occurring over a number of years in one particular NHS trust. Significantly, the report also identified a "learned helplessness" among medical and nursing staff, resulting in disengagement of health care professionals from management. ${ }^{4}$ Subsequent reviews of other NHS provider organizations have unearthed similar problems with a focus on targets and efficiency savings dominating board agendas and organizations losing sight of the patient. This has been viewed widely as something that needs fixing, and a significant element in the solution has been to invite clinicians to engage with system delivery, to use their voices and values in improving quality and productivity, while simultaneously controlling the costs of service provision. ${ }^{4-6}$

Clinicians, doctors in particular, have considerable influence in relation to health care expenditure, occupy the moral high ground of patient advocacy, and have a large measure of autonomy by virtue of their training and professional knowledge. Drawing upon the organizational theories of Mintzberg, health care organizations function as "professional bureaucracies" in which the continually evolving expertise of skilled and knowledgeable workers exercises a high degree of degree of control over the delivery of services. ${ }^{7}$ In a professional organization, workers' autonomy is regulated by external professional bodies, contrasting with a "machine bureaucracy", where the organization itself designs and enforces standards through strong line management structures. Professional bureaucracies create an inverted power structure, where frontline staff have greater influence over daily decision-making than those who, through formal positions of authority, are responsible for managing the service. ${ }^{5,8}$ In such a system, the ability of managers to influence clinical decision-making is constrained since clinical professionals form the "operating core" of health organizations, thereby controlling the means of production. ${ }^{9}$

According to Ham and Dickenson, ${ }^{10}$ this has three significant implications for health care organizations: key leadership roles are played by professionals; leadership is dispersed or distributed among staff and not limited to individuals in formal managerial roles, and the system requires collective leadership, ie, teams that bring together leaders at different levels. In understanding the relationships and power dynamics within health care organizations, it becomes evident that significant clinical change is impossible without the cooperation and support of clinicians at all levels. The operating core of most health care organizations consists of a large body of doctors in postgraduate training, resolutely engaged at the front line of patient care. "Junior" doctors, then, are the perfect tool for initiating, championing, and delivering change and improvement in the quality of care.

\section{Postgraduate medical training in the UK}

There are around 60,000 junior doctors (In the UK, the term "junior doctor" is used to describe a qualified doctor who has yet to be placed on the General Medical Council's specialist or general practice register. Junior doctors are normally "trainees" enrolled in a postgraduate training program and work under the supervision of "seniors", usually registered consultant specialists or general practitioners) in postgraduate training programs in the UK, with multiple agencies responsible for different aspects of the training. Setting and monitoring professional standards is primarily a role of the General Medical Council and Royal Colleges, funding is controlled centrally from the relevant Department of Health and dispersed via various bodies such as Health Education England or NHS Education for Scotland, and those delivering the training are situated in a variety of a community, integrated, and hospital settings. Unlike undergraduate students, postgraduate trainees do not have a university structure to manage their placements, programs, or the progression of individuals. Historically therefore, a "deanery" has sat as "an organization in the middle", providing an umbrella for postgraduate medical education and training, controlling the funding flows, ensuring training is delivered to curricular specifications, and that quality standards are monitored and maintained.

There is broad agreement that the prime purpose of postgraduate medical training is “... to ensure that specialized doctors competently address the medical needs of the community" (p 3), ${ }^{11}$ an aim reiterated in a recent report on the future of postgraduate medical education and training, The Shape of Training. ${ }^{12}$ Indeed, training structures in the UK have been in evolution since the publication, in the 1990s, of the Calman report. ${ }^{13}$ Predominantly concerned with improving specialist hospital training, this report resulted in the introduction of specialist registrar posts with explicit curricula, regular assessments of progress, and time-limited specialist training. Alongside this development was the implementation of European Working Time Directive later, European Working Time Regulations - restricting junior doctors to a maximum of 58 hours per week by 2004 , with a further reduction to 48 hours by 2009. Many doctors 
traditionally worked much longer hours, and these changes reduced the degree to which the NHS could rely on doctors in training for service delivery and, correspondingly, decreased the amount of time doctors would have available for training.

In order to address these issues, postgraduate training was further reformed - under the banner of "Modernising Medical Careers" - predominantly to accelerate the production of competent specialists. "Modernising Medical Careers" led to the creation of a 2-year foundation program, followed by basic specialist training in a broad specialty grouping (eg, core medical training), and then higher specialist training in a specific specialty (eg, neurology). ${ }^{14}$ The aim was to provide doctors with wide initial breadth of training, which would ultimately be shorter by virtue of a more structured program later on. ${ }^{15}$ Explicit curricula for each specialty (there are 67 in the UK with 35 subspecialties) were introduced alongside a wholesale revision of training standards and accountabilities.

Since then, there has been a gradual shift in curricula emphases, from the dominance of technocratic expertise to the foregrounding of "nontechnical skills". ${ }^{16,17}$ A range of generic competencies have found their way into postgraduate medical education and training, particularly in the areas of leadership, research, and education. This recognition that doctors are an integral part of a health care system, rather than isolated and autonomous clinical professionals, is further underscored by an increasing focus on quality improvement and population health, and most recently a rediscovery of the patient at the heart of care, with attention turning to issues such as coproduction, patient engagement, and supported self-management. ${ }^{18}$

With these changes has come the recognition that the potential of the trainee body (junior doctors), a large sector of the NHS workforce, is largely untapped. ${ }^{19}$ Furthermore, there is a risk that this future generation of influential health care professionals may not be adequately engaged with the "business" of health care provision, with the consequence that our professional bureaucracy continues to normalize around professional rather than system drivers.

\section{Why engage junior doctors?}

At the heart of postgraduate medical education is a managed tension between service and training, with the learner also as employee. ${ }^{20}$ Junior doctors rotate frequently between different service providers as part of their training in order to achieve their competency-based curricula, but also represent the front line of clinical service delivering, for example, $80 \%$ of ward-based activity. ${ }^{21}$ Due to their transient nature within organizations, junior doctors are often disconnected from their employers and viewed as a temporary workforce providing service. However, this peripatetic group is exposed to a myriad of different working practices within a wide range of service providers and have the potential to disseminate good practice as well the ability to identify areas for change. ${ }^{22,23}$

With recognition that today's junior doctors will be tomorrow's clinical leaders, the importance of the development of management and leadership has been highlighted in many policy documents, including an independent inquiry into "Modernising Medical Careers",

$[\ldots]$ the doctor's frequent role as the head of the healthcare team and commander of considerable resources requires that greater attention is paid to managerial and leadership skills irrespective of specialism (p 90). ${ }^{21}$

Many commentators have expressed concern that the ability of doctors in training to influence change is not being harnessed and are an underused resource, which if mobilized could significantly improve quality and safety of patient care. ${ }^{10,14,19,24}$ A recent survey of over 1,500 doctors in training found that $91 \%$ had ideas for workplace improvement, but only $11 \%$ had been able to implement these. ${ }^{22,25}$ This is a waste. Leadership development of this group of youthful energetic junior doctors should be an essential part of "improving health, reducing its variation and doing so in an affordable way" (p 466). ${ }^{26}$

\section{What is clinical leadership?}

As understood in Anglo-American contexts, ${ }^{27}$ the terms "leadership" and "management" are sometimes used interchangeably, ${ }^{28}$ but within the health care literature they tend to describe different approaches to how change can be achieved.

Management is sometimes viewed as a pejorative term, particularly in the public sector, and the discourse of leadership provides a more attractive narrative for professionals, enabling policymakers to engage professionals into activities they desire, such as service reform. ${ }^{29-31}$ While this may be seen as a cynical tactic to co-opt professionals into the organizational arena in order to control their activity, ${ }^{32}$ it may also reflect a genuine recognition that to address the "wicked" problems faced by health and social care organizations, the particular knowledge and insight professionals bring are crucial for effective negotiation, influence, and persuasion with a variety of stakeholders in an increasingly complex system. ${ }^{33}$

Definitions of leadership are many and contested, but most commentators agree that leaders motivate, inspire, and 
align strategy to establish direction for individuals and the systems in which they work, while managers are process driven and use problem solving to direct individuals and resources to achieve goals already established by leadership. ${ }^{1,34,35}$ As described in an influential report from the King's Fund, leadership, management, and administration are interdependent since ... without leadership there can be no effective management - because the organization will not know what it is meant to be doing - and without good administration management can be rendered ineffective (p 1). ${ }^{36}$

If we accept Mintzberg's theory that health care organizations exhibit an inverted power structure, a new leadership paradigm emerges. Those providing front-line service have significant influence over the operational activities, resulting in a range of patient- and population-related outcomes compared to those who occupy hierarchical positions of authority. Hence, clinical leadership becomes an inclusive endeavor. By engaging champions of health care quality at service-level, behaviors and attitudes on the front line can be aligned with organizational vision, ensuring that the needs of the patient are central in the organization's aims and delivery. This view of clinical leadership appeals to clinicians as it frames health care management around the leadership of change and improvement for the safety and quality of patient care. It is a discourse that also replaces the previous one of professionals as the cause of problems in public service organizations and, crucially, begins to view them as part of the solution.

\section{Leadership models, trends, and contexts}

Swanwick and McKimm ${ }^{35}$ frame leadership as a social construct, influenced by the preoccupations, sociopolitical system, and cultural values of the time. The leadership theories and models espoused will influence the discourses adopted and reflect societal views of how systems are or should be organized. This is clearly crucial when we consider leadership development, as how leadership is conceptualized will profoundly influence approaches taken in the name of its development. In the following sections, we summarize some of the previous century's most influential leadership models and consider what might be needed for a 21 st century health service.

\section{Trait theory}

In the first half of the 20th Century, "trait" theories emerged around the ideal of the "Great Man" proposing that great leaders (usually men, reflecting the position women had in society at that time) had a defined collection of personal attributes, including ability, sociability, motivation, and dominance. This theory is attractive to doctors given the weight placed on key personal characteristics in their selection process, but as Willcocks ${ }^{37}$ maintains, while many doctors may possess leadership qualities, these are not equally distributed and some doctors may be able to employ these in a clinical encounter, but not necessarily in the dynamic group context of leadership. Literature reviews in the 1970s failed to consistently identify the personality traits that distinguish leaders from nonleaders, although one more recent review has identified a weak positive correlation between successful leaders and three of the "big five" personality factors - extroversion, openness to new experience, and conscientiousness. ${ }^{38}$ Additionally, leaders had a weak negative correlation with neuroticism, but interestingly, no relationship was found to the extent to which the leader is agreeable. Another review in the context of school leadership found less emphasis or correlation on these "innate qualities" with successful leadership. ${ }^{39}$

\section{Leadership styles}

From the 1950, greater emphasis began to be placed on leadership styles and behaviors rather than personal characteristics. In part, this was a reaction to the deficiencies of the trait approach and its failure to recognize the context in which leadership occurred. The shift in theory focused on two aspects - how leaders made decisions and on what they were focused. Many taxonomies for decision-making styles developed, but the most famous is perhaps that of Tannenbaum and Schmidt ${ }^{40}$ who describe a continuum of leadership behavior from autocratic ("do as I say") to abdicatory ("do what you like"). Other styles embraced team management, where leadership is focused on results or the people in the organization, ${ }^{41,42}$ or an authoritative manner which mobilizes empathetically toward a vision..$^{43}$ These styles are attractive for clinicians in leadership roles as they embrace balancing the needs of patients and team members within an environment where resources are constrained and management targets need to be met.

\section{Contingency theories}

In order to recognize the complexity and context of different situations, contingency theories became popular in the 1960s, the concept being that leaders should adapt their style to the competence and commitment of followers, using a range of interventions, such as directing, coaching, supporting, and delegating. Such an approach requires not only awareness of 
these styles of leadership, but also the recognition of when a particular approach is required with appropriate enactment. A criticism of contingency theories is that they are highly dependent upon who defines the situation in question. ${ }^{44}$

\section{Transformational leadership}

In the 1980s, a new paradigm of transformational leadership emerged, arising in part from the recognition that previous leadership approaches failed to account for the fact that environments are subject to continual change..$^{45}$ Existing models tended to be transactional and managerial in nature, which were useful to plan and organize at times of stability, but inadequate when describing how to lead people or organizations through periods of significant change. In the transformational model, leaders release human potential through empowerment and development of followers. Leaders articulate the values and direction of an organization, work of individuals within the organization is aligned to the achievement of these long-term goals, and followers are nurtured thereby strengthening organizational culture and engendering a commitment to move toward a shared envisioned future.

One of the problems with a transformational leadership approach is the tendency toward the veneration of individual leaders as "tsars". This led in the 1990s to a wave of charismatic individuals sweeping into "turnaround" failing organizations using their dominant personality and self-confidence to influence others, while exhibiting strong role modeling, extolling high expectations, and articulating ideological goals. As a complete antithesis, servant leadership offers a quieter stewardship approach where leaders facilitate growth and development, and serve the needs of the community by persuasion rather than coercion with empathetic listening and encouragement to collective action. ${ }^{46}$ Nevertheless, "heroic" transformational leadership has proven to be an enduring model, being incorporated into many public sector frameworks including the UK's NHS Healthcare Leadership Model. ${ }^{47}$

\section{Distributed leadership}

This "post heroic" model considers leadership not to reside in one individual but instead the focus is on "... organisational relations, connectedness, interventions into the organization system, changing organization practices and processes" (p 6). ${ }^{48}$ Boundaries to leadership are open, encompassing multiple individuals whose expertise is distributed across professional and organizational boundaries, building upon social capital for innovation, collaboration, and improved outcomes. ${ }^{49,50}$ Leadership shifts from the focus on individual qualities of a leader at the top of an organization to the process of leadership within an organization. It offers the exciting opportunity where leadership development is not about creating more leaders, but systems where leadership is everyone's responsibility and enabled by a diverse range of groups and individuals. ${ }^{23}$ Distributed leadership moves beyond the lonely model of heroic leadership to a shared, adaptive, and collaborative approach that forces leaders to focus on systems of care and not just organizational delivery of results through followership.

So what is it then about the clinical context that influences the way we might think about "clinical leadership", and medical leadership specifically. As we have discussed, health systems are complex. They have range of aims and objectives (not simple profit/loss) controlled through professional networks often with an absence of direct line management or contractual control, with colleagues who may have completely different sets of accountabilities and who often are situated in completely different organizations. Health and social care systems in the UK are also incredibly diverse in terms of the culture, ethnicity, sex, and educational background of its workforce.

Evidence from a study of 13 organizations shows that a team structure working on a basis of trust will create "a mutually reinforcing circle of benefits" (p 370). ${ }^{51}$ This supports the view that a top-down approach of leadership is doomed to fail in a complex and uncertain environment. The distributed leadership model enables local decision-making by individuals, who guided by organizational vision, values, and strategic intent do not then need excessive hierarchical structures. This approach shifts away from a focus on individual leadership characteristics or styles to a process of "engagement", where the mobilization, commitment, and alignment of front line staff create a culture of leadership within an organization. ${ }^{36,50}$

But is this enough? Health care is increasingly delivered by organizations working together, across the traditional boundaries of health and social care toward a set of shared objectives. This requires leadership that not only is distributed vertically within individual organizations, but horizontally across whole health care systems, where the leadership, at any one moment, might be taken by anyone, from anywhere. This requires an even more sophisticated approach and in a series of review publications by the Kings Fund, a consensus is building that such a challenging environment requires leadership that is not only distributed, but also collective, collaborative, and, above all, compassionate. ${ }^{52}$ 


\section{Does clinical leadership make a difference?}

Effective leadership is an important component of successful health care organizations, ${ }^{53,54}$ whereas lack of leadership can be associated with organizational failure., ${ }^{4,55}$ Veronesi et $\mathrm{al}^{56}$ suggest clinical leaders influence health care system outcomes since they have the expert knowledge of the core business of health services and a deeper awareness of what patient care involves ... [to] make better informed decisions regarding service design and resource allocation.

Forbes et a ${ }^{57}$ describe "role design" for clinician managers, who, instead of replicating the role of hospital managers, use their unique voice to focus on clinical priorities.

There is a growing literature on the benefit of clinicians in management and evidence that high-performing medical groups build relationships with managers, with an emphasis on clinical quality. ${ }^{58,59}$ Clinicians in senior management roles tend to enhance operational outcomes for hospitals and organizations perform significantly better than those with lower levels of clinician participation. ${ }^{60-63} \mathrm{~A}$ review conducted by the Academy of Royal Medical Colleges in the UK concluded that chief executive officers from high-performing institutions engaged clinicians in dialogue and joint problem solving. ${ }^{64}$ Goodall ${ }^{65}$ demonstrates that hospital quality scores are $25 \%$ higher in physician-headed hospitals compared to those with chief executive officers from nonmedical backgrounds. More recently, research undertaken by Veronesi et $\mathrm{al}^{56}$ in the UK tentatively suggested that the "share of doctors" on the board made most difference, and this relationship became less robust when other health professionals were involved at board level. This chimes with Dorgan et $\mathrm{al}^{6}$ who investigated organizations across seven countries and suggested that having higher proportions of medically qualified managers results in more effective management practices.

It can be difficult to quantify the exact impact of clinical leadership on service quality; however, studies do exist which suggest improvements in various domains. A study of hospitals in Michigan found that by using bed occupancy rates and market share as performance measures and by excluding clinical leaders from strategic decisions resulted in lower hospital performance. ${ }^{66}$ Keroack et al ${ }^{67}$ ranked health care institutions using a composite index of quality and safety that was developed to incorporate domains identified as attributes of an ideal health care system. High performance scores for organizations were associated with organizational leadership that prioritized patients, focused on quality and safety, used clear systems of accountability, sought continual improvement as evidenced by results, and emphasized collaboration between different staff groups to make use of their varied expertise. Commissioned by the King's Fund to inform the leadership commission, Baker ${ }^{68}$ used case studies to identify factors accounting for success in high-performing systems; again, clinical leadership that prioritized patients, quality and safety, and that promoted collaborative working between different professional groups was consistently present in all of these institutions.

\section{Barriers to clinical leadership development}

It becomes increasingly clear that clinical leadership is a central ingredient to improve the quality of health care. ${ }^{36,69}$ It is an essential component to align process redesign for business operations and quality assurance, with clinical agendas pertaining to patient care, service development, and professional development for high quality services. Yet, despite the wealth of evidence concerning the importance of clinical leadership in health care organizations, it remains a variable constituent of health systems. Darzi ${ }^{70}$ concluded in the NHS Next Stage Review that "leadership has been the neglected element of the [health service] reforms of recent years" (p 66). A report by the King's Fund again highlighted the failure of the NHS to engage doctors in management and leadership and that "management and leadership needs to be shared between managers and clinicians and equally valued by both" (p xi). ${ }^{36}$

The evidence for this lack of engagement highlights three factors that prevent clinical leadership from being embraced: reluctance of doctors to enter into management, weak incentives for leadership activities, and the lack of provision of training or nurturing mechanisms for young clinicians wishing to engage with this aspect of health care provision.

$\mathrm{Ham}^{8}$ recognizes that change is incremental, slow, and painstaking work, which can be at odds with policymakers and taxpayers who want to see quick results. There is a mismatch between those introducing the bottom-up incremental changes for effective and enduring service improvement compared to the expectations of policymakers who want "big bang reforms" (p 2). ${ }^{8}$ Clinicians are used to the immediacy of delivering patient care and are reticent to shift their focus to leadership, where rewards are longer term and often not easily defined..$^{71}$ Among doctors, the emphasis throughout training is on "individual action and accountability" (p 483), and they often cannot conceive how leadership can be relevant to patient care. ${ }^{72}$ Doctors also face considerable pressure to meet clinical targets, and a recent British Medical Association review found a consistent barrier for 
engagement in leadership to be a lack of time and resources to meet clinical priorities. ${ }^{73}$ So, time away from patient care to concentrate on management and leadership is perceived as a distraction unless doctors have robust evidence for the value of such activities.

Despite the recent foregrounding of clinicians in management and the emergence of a new definition of the medical professional, tribalism and an ingrained distrust of doctors entering the management sphere persists. Clinicians function in an era of evidence-based practice and can have entrenched views about the credibility and value of leadership. Degeling et $\mathrm{al}^{74}$ accept that clinical leaders are well placed to take forward NHS reforms, but find reluctance among medical managers to question the perceived dominance of medicine in clinical settings, thus making collective working difficult. On the other side, a culture of "antimanagerialism" exists where clinical leader colleagues are described as having gone "over to the dark side". ${ }^{71,75,76}$

Mintzberg $^{77}$ ( $p$ 199) believes that clinicians and clinical leaders fail to understand the role of professional managers, perceiving them as servants in the system as opposed to powerful allies, seated at "the locus of uncertainty" and able to influence the power afforded to clinicians within the organization. Edmonstone ${ }^{78}$ is brutal in chastising clinicians for working in uniprofessional silos, which he claims prevents effective and safe delivery of health care. He offers an alternative where effective organizations have models of service delivery based upon supportive team structures, learning from mistakes, and instigation of service change.

Alongside these issues, incentives for entering into such activities are weak. There is no predefined career structure for service leadership, with promotion and remuneration linked to clinical activities as opposed to participation in management. Measurement of quality of care is imperfect and rudimentary; therefore, it is not possible to reward those who build the best services unlike those who receive financial accolades for clinical or research activity. Moreover, traditional role models for clinicians are individuals who excel in the practice of their profession and not organizational leaders. Leadership is not viewed as equivalent to research, where participation in the latter results in career advancement, prestige, influence, promotion, and financial reward. ${ }^{2}$

For learners in the health care professions, there has been little provision for clinical leadership development in the past, with training and education in this area being largely absent from core curricula. However, this is changing. The undergraduate curricula developed by the Nursing and Midwifery Council (2010) and the General Medical Council
(2009) have started to reflect the need for clinical leadership development in the preregistration workforce, and all postgraduate curricula now contain intended learning outcomes in the area of leadership and management. But embedding a leadership competency framework into professional curricula is merely a start. ${ }^{79}$

The bulk of the professional workforce are already active in the NHS and often represent the front line of service, whom Swanwick ${ }^{19}$ states "have the capability, energy, and enthusiasm to transform the NHS" (p 117). In Denmark, an explicit aim to increase the number of doctors stepping into leadership roles has shifted the culture to not only impact medical behavior and curricula, but also form the basis of appointment criteria. ${ }^{80}$ Danish postgraduate doctors receive mandatory leadership training based upon the CanMEDS roles framework, ${ }^{81}$ and after consultant appointment, they are expected to participate in leadership development programs. ${ }^{10}$ A similar robust program of systematic leadership development utilizing CanMEDS is also evident in the Netherlands. ${ }^{10}$

In their extensive review of theoretical and empirical literature of leadership and leadership development, Day et $\mathrm{al}^{82}$ conclude that while leadership is something that all organizations value, they are much less interested in which theory or model is the "right" approach, instead they want to know how to develop leaders and leadership as effectively and efficiently as possible. In the next section of this paper, we provide a review of some of the leadership interventions for junior doctors that have been utilized in the UK and attempt to identify the hallmarks of effective leadership development in this context.

\section{Leadership development of junior doctors in the UK}

Against this backdrop of evidence for the impact of clinical leadership and the significant issues surrounding its practice, a raft of interventions has been deployed in an effort to engage young clinicians in leadership activities. Leadership development interventions in common use range from oneday workshops, short courses, experiential programs to postgraduate masters and doctoral awards. A number of these approaches are now explored in more depth.

\section{Competency frameworks}

In early 2000, the NHS in England commissioned Hay Group management consultancy to identify a core set of leadership qualities associated with success at chief executive and executive director levels, which lead to the production of 
the Leadership Qualities Framework published in 2002 and further reviewed in $2006 .{ }^{83}$ This identified 15 personal, cognitive, and social qualities essential for successful leadership across health services. These qualities are clustered into three broader domains: personal qualities, setting direction, and delivering the service. This led to the development of the Medical Leadership Competency Framework (MLCF) by the Academy of Royal Medical Colleges. The MLCF codifies 20 elements essential for effective medical leadership that are divided into five leadership competency domains needed to plan, deliver, and transform health services. A perceived advantage of the MLCF is its continuous nature being purposefully designed for championing leadership on the front line commencing from medical school and crucially to make this a "normal part of their roles as doctors" (p 110). ${ }^{68}$ It embeds acquisition of leadership and management skills as a core function as opposed to an extracurricular activity. While these competency domains may be necessary for clinical leadership, they are by no means sufficient to build up the social capital required for collaborative and supportive change. ${ }^{84}$

In relation to the wider NHS in England, an NHS Leadership Academy was set up in 2012 as an umbrella organization to bring together all national activity supporting leadership development in health and NHS funded services. In 2013, it launched an array of national programs that it described as "the most far-reaching and comprehensive leadership development portfolio the NHS has ever developed", designed to support staff from a diverse range of clinical and nonclinical backgrounds to create "a more capable and compassionate" health care system. ${ }^{85}$ The programs range from online introductions through master-level courses to action learning orientated offerings for senior leaders. In parallel, the Academy has developed a new framework to underpin its work, the Healthcare Leadership Model. ${ }^{86}$

Opponents of competency frameworks contend it is a reductionist approach, ${ }^{87}$ steering learners toward a tick box attitude and neglecting the emotional intelligence needed for leadership. ${ }^{88}$ Edmonstone ${ }^{89}$ suggests that leadership needs to move beyond explicit knowledge embodying competence (solving "tame" issues which are clear and unambiguous problems), but neglects tacit knowledge, which is learned through experience and creates capability to tackle "wicked" problems. McKimm and Swanwick ${ }^{90}$ agree that the competency approach can reinforce particular conceptions of leadership, such as a trait-based approach, but are more conciliatory and suggest that frameworks like the MLCF serve to raise the profile of leadership and provide a common language to use in interrogating its nature.

\section{Talent management}

Forbes et $\mathrm{al}^{57}$ identified two roles generally taken by clinicians engaged in management - investors pursuing management as an alternative to clinical medicine and reluctants assuming management roles as protective custodians for their specialty from others. The authors identified that neither the reluctants nor investors had sufficient understanding or contact with management prior to taking on their roles, and therefore advocate earlier preparation of clinicians to develop a "managerial self" and a process of "management talent", whereby clinicians interested in management are identified at an earlier point in their careers and supported to develop these skills. Spehar et $\mathrm{al}^{91}$ found path dependency and social pressure to influence clinicians' decisions to enter into management positions, and they also suggest formalized pathways to attract and retain early stage clinicians into management. Talent management systems and whole organization approaches to leadership development are now widespread in the NHS, but because of the transient nature of the junior doctor population, they tend to eschew this large section of the clinical workforce.

\section{Shared learning}

In deconstructing the physical and conceptual barriers between managers and clinicians, programs have been developed with a shadowing approach where seemingly opposite sides of the leadership divide, meet and understand, and appreciate and collaborate for enhanced delivery of care. In 2008, NHS London set up 'Prepare to Lead' - a leadership development mentoring scheme, which ran complementary to clinical training. This scheme matched selected high potential registrars or newly qualified general practitioners into mentoring relationships with senior health care leaders from the NHS or the private sector. ${ }^{92}$ The year-long program involved action learning sets and mentoring by senior clinical leaders to equip these clinicians with the ability to progress to strategic organizational level responsibilities in their future careers.

Other examples include pairing of a management trainee with a foundation level junior doctor who work together over a period of 6-9 months to enhance patient care. ${ }^{93}$ Hawken et $\mathrm{al}^{97}$ argue that this experience allowed doctors and managers to obtain shared learning and understanding of "... areas of practice and expertise at an early stage of their careers and to begin developing leadership skills", which they hope would normalize this "integration at a much earlier point of a medical career". This approach has been further developed in schemes where registrars were paired with middle level 
managers within organizations to provide practical leadership experience and education. ${ }^{94,95}$ These programs used a combination of informal conversation, shadowing, workshops, and improvement skills to enable participants to better understand each other's perspectives and to drive learning. According to Klaber and Lee, ${ }^{94}$ short-term gains have included demonstrable changes in quality of patient care and greater efficiency; however, more exciting is the longer term gain of cultural change between managers and junior doctors, allowing for more collaborative working in the future.

\section{Secondments and clinical fellowships}

In recent years, secondments and clinical fellowships have become a popular way for junior doctors to "dip a toe" into a different world and experience clinical leadership, policy making, and strategic decision-making outside of the clinical training environment. There are a number of national and international fellowships that have been developed to enable identification of future leaders and provide a mixture of training, mentoring, and leadership experience. ${ }^{96}$

The National Medical Director's Clinical Fellow Scheme provides doctors in training with the unique opportunity to spend 1 year in a national healthcare-affiliated organization to develop their skills in leadership, management, strategy, project management, and health policy. ${ }^{97}$

This scheme has grown from a pilot scheme in 2008 and affords junior doctors the opportunity to work as clinical advisors to senior medical directors within organizations as diverse as NHS England, Bupa, National Institute of Clinical Excellence, and the Royal Colleges. The scheme is a mixture of day-to-day experiences within the organization, learning sets, and personal development sessions, which can focus on public speaking, publication, or networking. Advantages of this scheme include the opportunity for junior doctors to understand organizational function, decision-making, and policy implementation within health systems. ${ }^{98}$ It has helped shape personal careers for previous incumbents and offers an insight into theory and practice of leadership.

In London, a highly successful 12-month "out of program" experience for a cohort of junior doctors was designed to develop the organizational and leadership capability for future roles as clinical leaders. ${ }^{99}$ Now in its 7 th year, the scheme has expanded to not only include doctors in training, but also other health care professionals in their early careers, all of whom work for a medical or clinical director of an NHS organization. ${ }^{100}$ Participants undertake a bespoke development program, while actively leading a change management project. The scheme also has an academic component with participants completing an accredited postgraduate certificate as well as a personal development focus incorporating workshops, coaching, mentoring, and action learning sets. ${ }^{24}$

International schemes include the Harkness Fellowships in Health Policy run by the Commonwealth Fund in USA. ${ }^{101}$ These fellowships in Health Care Policy and Practice provide a unique opportunity for mid-career health services researchers and practitioners from Australia, Canada, France, Germany, the Netherlands, New Zealand, Norway, Sweden, and the UK to spend up to 12 months in the USA, conducting original research and working with leading US health policy experts. A stipend is provided, and fellows divide their time between research under the mentorship of a host organization in the USA and learning about health policy as a group.

There is no doubt that the fellowships described above offer junior doctors an invaluable opportunity to expand their clinical training to develop an appreciation of managerial, leadership, and policy concerns. As a junior doctor, much of this can seem opaque, and these opportunities may help to illuminate these important areas. Most fellowships ensure leadership development is rooted in project-orientated workbased activities. However, Nicol ${ }^{96}$ suggests there may be lack of clarity as to the ultimate aim of fellowships which may develop the "hero" clinical leader, but may also disengage others when faced with lack of clinical credibility or authority. Additionally, is the learning that arises from such fellowships harnessed and disseminated when the fellows return to their clinical roles after their period of secondment? Stoll et $\mathrm{al}^{99}$ recognize that such fellowships are a healthy start as they begin to "spawn[ing] clinical leadership development throughout the wider health care system" (p 284), but wholesystem engagement of doctors in training requires more than a fellowship that is available only to a small number of self-selected, highly motivated individuals.

\section{Quality improvement}

As the emphasis moves away from the "hero" clinical leader and more toward a culture of learning throughout and within the organizations, quality improvement has become the tool with which to instill distributed leadership. Bohmer ${ }^{72}$ described this form of leadership as leadership with a small " $L$ " which is exercised at the level of team, ward, unit, and department, and the goal is to oversee the local system of care in which patients receive care. All members of the health care team, including junior doctors, are part of this leadership; it does not require doctors to step out of clinical 
training - instead they are actively part of the front line where they initiate change. ${ }^{102}$ In his review of roles of leaders in high-performing health care systems, Baker ${ }^{68}$ concludes that despite the large size and complexity of such organizations, there are a number of factors that contribute to their success: consistent leadership which "embraces quality as a business strategy" ( $p 23$ ), building staff capability to support performance improvement, and framing success as better care for patients.

These aspirations align with Berwick's declaration in "A promise to learn - a commitment to act", [g]ive the people of the NHS - top to bottom - career-long help to learn, master and apply modern methods for quality control, quality improvement and quality planning (p 10). ${ }^{103}$

Junior doctors often are able to identify small system problems which when combined can result in large-scale inefficient delivery of health care. Roueche and Hewitt ${ }^{23}$ describe an educational program in quality improvement offered to doctors in training to address such issues. By providing junior doctors with these skills but also empowerment to make improvements to the systems they see, they have the agency to affect change at the operating core and there is potential to impact the quality of care delivered significantly. This does not require formal "leadership" development, but the right tools and knowledge alongside a nurturing relationship with management. Gamble and Vaux $^{102}$ suggest that quality improvement offers capability and capacity for junior doctors to make a difference at a local level. They believe it has the ability to counteract "learned helplessness", which can infect those on the front line when they are disengaged with management or when there is a lack of robust methodology or infrastructure to support identification, initiation, and implementation of change.

\section{How do we learn to lead?}

So, how do we set about, more effectively, developing this range of understandings, skills, and competencies? What frameworks can serve to guide those who develop and deliver programs for the junior doctor workforce?

We have seen a move in recent years to concepts of leadership that take us beyond historical (but continuingly pervasive) conceptions of leadership development that focuses on training individuals to take on increasingly responsible and complex roles involving a shift in emphasis from the development of individual leaders to that of leadership development. Leadership development is an investment in social capital, which builds the organization's leadership capacity at all levels, as well as the human capital of individual competence and capability.

Within this changing paradigm, a number of secondary themes in the wider leadership development literature can be identified and summarized as an evolution in thinking about:

- The educational approach - moving from the provision of training to a focus on ongoing leadership development embedded in systems and organizational processes (eg, appraisal);

- Where learning is situated-relocating from the classroom to the workplace;

- How career development is considered - paradoxically reprioritizing from organizational requirements to a consideration of individual needs.

These trends point us in the direction of some particular strategies for program design and the selection of appropriate leadership development interventions. The design principles that emerge move us from a predetermined "course" to a personalized "program" rooted in real-world experience. But what does that look like in practice? No two leadership development programs will be the same, but a number of potential interventions are in common use, summarized in Figure 1. The key message here is that it is not the interventions that are the most important thing, but how they are assembled programmatically and contextualized, and indeed, valued within the organizational environment.

Swanwick and McKimm ${ }^{104}$ summarize a set of principles for design of leadership development namely that they should be:

- Practical: through the incorporation of the development of key skills such as coaching, change management, and negotiation

- Work oriented: by including project work as a key component supported by action learning sets

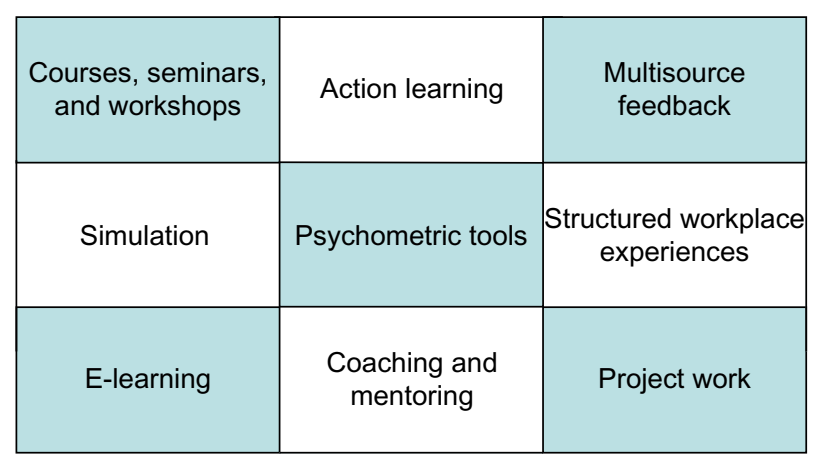

Figure I Common interventions in leadership development programs. 
- Supportive of individual development: through $360^{\circ}$ feedback, coaching, and mentoring

- Link theory to practice: through the provision of selected leadership and management literature, relevant to the educational context

- Build networks: through action learning, coaching, and social networking.

At the heart is a debate about whether leadership can be learned, ie, is leadership a function of personality or a learned set of behaviors. In reality, it is probably a mix of the two. So, developing a sense of who you are and how you impact others is every bit as important as the syllabic content. The implications of this are then the need to shift from instructor-centered teaching to learner-centered personal transformation.

\section{Leaders or leadership?}

As Bolden ${ }^{105}$ (p 7) explains if we do consider leadership to be a "collective process", then leadership development is not about sending selected individuals to high-level courses and encouraging others to "follow the leader". The model of the leader who will be the "superhero" is not fit for purpose in the current health care environment (p 18). ${ }^{36}$ By choosing to develop "leaders" as opposed to relationships between individuals, Edmonstone ${ }^{106}$ contends that leadership can become divorced from the context in which it occurs and fails to harness the importance of teams and networks, making leadership a "multi-professional and multi-agency concern" ( $\mathrm{p}$ 290). He is critical that most leadership activities in the NHS have been based upon developing individual leaders rather than that of "health care leadership", which is much more challenging and complex.

Successfully led organizations require empowered multiprofessional teams where any one member can step up to the plate to lead. But West et $\mathrm{al}^{52}$ point out that our approach to leader and leadership development in UK health care is "distorted by a preoccupation with individual leader development (important though it is), often provided by external providers in remote locations" (p 4). The report reiterates the view that successful organizations are "leader-ful" not just "well led", highlighting that in comparison with the literature on leader development, "the development of the capacity of groups and organizations for leadership as a shared and collective process - is far less well explored and researched" (p 3$)^{52}$ and urge that we begin to look in that direction.

\section{Conclusion}

There is a growing body of international evidence that when clinicians are involved in strategic decision-making at an organizational level, they are able to add their voices to enact change, which is not only resource friendly but enhances clinical and operational outcomes. Clinical leadership has become the "high profile" conduit to enable this to occur.

According to Baker and Denis, ${ }^{107}$ three elements are required to develop medical leadership in health care organizations: encouragement to formal leadership roles; the promulgation of a collective understanding of organizational leadership, occurring in a coordinated manner at all levels; and aligning development of leadership with clear quality and safety improvement goals at strategic and operational levels in the organization. Gilbert et $\mathrm{al}^{22}$ state that when doctors in training attend leadership training, they have greater desire and perceived ability to contribute to improvement in the NHS.

An express wish of the Medical Director of NHS England has been that clinicians should routinely be shortlisted senior positions in health care. ${ }^{24}$ While this is a laudable aim, this may continue to perpetuate the historic model of command and control and a target-driven approach, when we should be striving for a model of "engaging leadership". ${ }^{108}$ This model is not about being an extraordinary individual but the emphasis shifts to "... teamwork, collaboration, connectedness and removing barriers to communication and original thinking". ${ }^{109}$ Leadership then becomes the "cognitive catalyst" (p 8) and is based upon a shared vision and has to encompass those on the front line. ${ }^{108}$ Perhaps, we can take a lesson from organizations such as Intermountain Healthcare or Kaiser Permanente in the USA, which invest in formal leadership development backed up with quality improvement skills that support this work. In essence, clinicians become involved in daily management of their institutions alongside long-term improvement work, translating into enhanced organizational performance and outcomes.

Bohmer ${ }^{74}$ states, leadership is not only about the big " $\mathrm{L}$ " (senior leadership roles in organizations), but is also the very important "leading of the micro-systems that have such an effect on care outcomes" (p 483). Leadership in highperforming organizations is not reliant on a charismatic leader; instead it is distributed in nature, where senior leaders define strategy, support execution of strategic initiatives, and engage individuals within the organization to lead on improvement activities. Ensuring that clinical leadership development has an equal weight within postgraduate training programs as clinical skill development is, therefore, essential, if we are to build health organizations with the capability for continual improvement in order that they might better meet the future needs of our patients and local populations. 


\section{Acknowledgment}

Thanks to Genevieve Holt for discussions regarding leadership development for junior doctors.

\section{Disclosure}

The authors report no conflicts of interest in this work.

\section{References}

1. The World Bank. Available from: http://data.worldbank.org/indicator/ SH.XPD.TOTL.ZS. Accessed April 8, 2015.

2. Jonas S, McCay L, Keogh B. The importance of clinical leadership. In: Swanwick T, McKimm J, editors. The ABC of Clinical Leadership. Chichester, UK: Wiley-Blackwell, BMJ Books; 2011:1-7.

3. Davis K, Stremikis K, Squires D, et al. Mirror, Mirror on the Wall, 2014 Update: How the US Health Care System Compares Internationally. New York, NY: The Commonwealth Fund; 2014. Available from: http://www.commonwealthfund.org/publications/fund-reports/2014/ jun/mirror-mirror. Accessed April 9, 2015.

4. Francis R. Mid staffordshire NHS foundation trust public enquiry; 2013. Available from: http://www.midstaffspublicinquiry.com/report. Accessed April 9, 2015.

5. Mountford J. Clinical leadership: bringing the strands together. In: Stanton E, Lemer C, Mountford J, editors. Clinical Leadership, Bridging the Divide. London, UK: Quay Books Division; 2010:159-166.

6. Dorgan S, Layton D, Bloom N, et al. Management in Healthcare: Why Good Practice Really Matters. London, UK: Centre for Economic Performance, LSE; 2010.

7. Mintzberg H. The Structuring of Organisations: A Synthesis of Research. Englewood Cliffs, NJ: Prentice Hall; 1979.

8. Ham C. Improving the performance of health services: the role of clinical leadership; 2003. Available from: http://image.thelancet.com/ extras/02art8342web.pdf. Accessed January 26, 2015.

9. Edmonstone J. Clinical leadership: the elephant in the room. Int J Health Plann Manage. 2009;24(4):290-305.

10. Ham C, Dickenson H. Engaging Doctors in Leadership: What We Can Learn from International Experience and Research Evidence? Coventry, UK: NHS Institute for Innovation and Improvement; 2008.

11. Borman E, O'Grady P. Postgraduate training. Policy paper prepared by the subcommittee on postgraduate training: Permanent Working Group of European Junior Hospital Doctors. Med Educ. 1997; 31:3-8.

12. Greenaway D. Shape of training: securing the future of excellent patient care. Final report of the independent review led by Professor David Greenaway. General Medical Council; 2013. Available from: http://www.shapeoftraining.co.uk/static/documents/content/ Shape_of_training_FINAL_Report.pdf_53977887.pdf. Accessed August 6, 2015.

13. Department of Health, Hospital doctors: training for the future. The Report of the Working Group on Specialist Medical Training. London, UK: Stationery Office; 1993.

14. Department of Health. Modernising Medical Careers: The Response of the Four UK Health Ministers to the Consultation on Unfinished Business: Proposals for Reform of the Senior House Officer Grade. London, UK: Stationery Office; 2003.

15. Madden GB, Madden AP. Has Modernising Medical Careers lost its way? Br Med J. 2007;335:426.

16. Fletcher G, Flin R, McGeorge P, et al. Anaesthetists' non-technical skills (ANTS): evaluation of a behavioural marker system. Br JAnaesth. 2003;90:580-588

17. University of Aberdeen. Anaesthetic non-technical skills (ANTS) system handbook; 2003. Available from: http://www.abdn.ac.uk/iprc/ documents/ants/ants_handbook_v1.0_electronic_access_version.pdf. Accessed April 8, 2015.
18. NHS England, Public Health England, Health Education England, Monitor, Care Quality Commission, NHS Trust Development Authority. Five Year Forward View; 2014. Available from: http://www.england.nhs.uk/ wp-content/uploads/2014/10/5yfv-web.pdf. Accessed April 8, 2015.

19. Swanwick T. Junior doctors: the best kept secret in the NHS? Postgrad Med J. 2011;88:1037.

20. Swanwick T. Postgraduate medical education: the same, but different. Postgrad Med J. 2015;91(1074):179-181.

21. Tooke J. Aspiring to Excellence: Final Report of The Independent Inquiry into Modernising Medical Careers. London, UK: MMC Inquiry; 2008. Available from: http://www.medschools.ac.uk/AboutUs/Projects/ Documents/Final\%20MMC\%20Inquiry\%20Jan2008.pdf. Accessed July 13, 2015.

22. Gilbert A, Hockey P, Vaithianathan R, et al. Perceptions of junior doctors in the NHS about their training: results of a regional questionnaire. BMJ Qual Saf. 2012;21:234-238. doi: 10.1136/bmjqs-2011-000611.

23. Roueche A, Hewitt J. 'Wading through treacle': quality improvement lessons from the frontline. BMJ Qual Saf. 2012;21:179-183.

24. Malby R, Edmonstone J, Ross D, et al. Clinical leadership: the challenge of making the most of doctors in management. Br J Hosp Manage. 2011;72(6):341-345.

25. Penlington C, Marshall P. Why Junior Doctors are Innovation Leaders [homepage on the internet]. London, UK: Health Services Journal; 2013. Available from: http://www.hsj.co.uk/leadership/why-junior-doctorsare-innovation-leaders/5060206.article\#.VT-QIUttfoA. Accessed April 30, 2015.

26. Brook R, Medical leadership in an increasingly complex world. JAMA. 2010;304(4):465-466.

27. Grey C. 'We are all managers now'; 'We always were': 'on the development and demise of management'. J Manage Stud. 1999;36(5): $561-585$.

28. Griffiths D, Sheehan C, Debar S, et al. Clinical leadership - the what, why and how. In: Stanton E, Lemer C, Mountford J, editors. Clinical Leadership: Bridging the Divide. London, UK: Quay Books; 2010: $1-14$.

29. O'Reilly D, Reed M. 'Leadersism': an evolution of managerialism in UK public sector reform. Publ Admin. 2011;88(4):960-978.

30. Wallace M, Tomlinson M, O'Reilly D. The mediation of acculturation: orchestrating school leadership development in England. Educ Manage Admin Leader. 2011;39(3):261-282.

31. Thorpe R, Gold, G. 2010. Leadership and management development: the current state. In: Gold G, Thorpe R, Mumford A, editors. The Gower Handbook of Leadership and Management Development. 5th ed. Farnham, UK: Gower; 2010;3-22.

32. Martin GP, Learmouth M. A critical account of the rise and spread of 'leadership': the case of UK healthcare. Soc Sci Med. 2012;74: 281-288.

33. Head B, Alford J. Wicked problems: implications for public policy and management. Admin Soc. 2015;47(6):711-739. doi: 10.1177/0095399713481601.

34. Kotter JP. Leading Change. Boston, MA: Harvard Business School Press; 1996.

35. Swanwick T, McKimm J. What is clinical leadership ... and why is it important? Clin Teach. 2011;8:22-26.

36. King's Fund. The Future of Leadership and Management in the NHS: No More Heroes. London. UK: King's Fund; 2011. Available from: http:// www.kingsfund.org.uk/sites/files/kf/future-of-leadership-and-management-nhs-may-2011-kings-fund.pdf. Accessed January 30, 2015.

37. Willcocks S. Doctors and leadership in the UK National Health Service. Clin Manage. 2005;13:11-21.

38. Judge TA, Bobo JE, Ilies R, et al. Personality and leadership: a qualitative and quantitative review. J Appl Psychol. 2002;87(4):765-780.

39. Earley P, Weindling D. Understanding School Leadership. Thousand Oaks, CA: Sage Publications; 2004.

40. Tannenbaum R, Schmidt W. How to choose a leadership pattern: should a leader be democratic or autocratic or something in between? Harv Bus Rev. 1958;36:95-101. 
41. Blake RR, Mouton JS. The Management Grid. Houston, TX: Gulf; 1964.

42. Adair J. Action-Centred Leadership. New York, NY: McGraw-Hill; 1973.

43. Goleman D. Leadership That Gets Results. Watertown, MA: Harvard Business Review; 2000:78-90.

44. Darmer P. The subjectivity of management. J Organ Change Manage. 2000;13(4):1-15.

45. Bass B, Avolio B. Improving Organizational Effectiveness through Transformational Leadership. Thousand Oaks, CA: Sage; 1994.

46. Greenleaf RK. Servant Leadership: A Journey into the Nature of Legitimate Power and Greatness. Mahwah, NJ: Paulist Press; 1977.

47. NHS Leadership Academy. Healthcare leadership model, 2013. Available from: http://www.leadershipacademy.nhs.uk/wpcontent/ uploads/dlm_uploads/2014/10/NHSLeadership-LeadershipModelcolour.pdf. Accessed January 30, 2015.

48. Turnbull James K. Leadership in context: lessons from new leadership theory and current leadership development practice. Available from: http://www.kingsfund.org.uk/sites/files/kf/Leadership-in-contextleadership-theory-current-leadership-development-practice-KimTurnbull-James-The-Kings-Fund-May-2011.pdf. Accessed January 30, 2015.

49. Bolden R. What is Leadership? Exeter, UK: University of Exeter Centre for Leadership Studies; 2004.

50. Bolden R. Distributed leadership in organizations: a review of theory and research. Int J Manage Rev. 2011;13:251-269.

51. Veronesi G, Keasey K. NHS boards: knowing the 'what' but not the 'how'. Publ Money Manage. 2010;30(6):363-370.

52. West M, Armit K, Loewenthal L, et al. The King's Fund. Leadership and leadership development in health care: the evidence base; 2015 . Available from: http://www.kingsfund.org.uk/sites/files/kf/field/ field_publication_file/leadership-leadership-development-health-carefeb-2015.pdf. Accessed April 8, 2015.

53. Rienstern J, Bisognano M, Pugh M. Seven Leadership Leverage Points for Organizational-Level Improvement in Health Care. 2nd ed. Cambridge, MS: Institute for Healthcare Improvement; 2008.

54. National Institute of Clinical Studies (NICS). Factors Supporting High Performance in Healthcare Organisations. Melbourne, Australia: NICS; 2003.

55. Walshe K, Shortell S. When things go wrong: how healthcare organizations deal with major failures. Health Aff (Millwood). 2004;23(3): 103-111.

56. Veronesi G, Kirkpatrick I. Vallascas F. Clinicians in management: does it make a difference?; 2012. Available from: http://www.sante.gouv.fr/ IMG/pdf/pacte_de_confiance_-_Clinicians_and_Boards.pdf. Accessed January 13, 2014.

57. Forbes T, Hallier J, Kelly L. Doctors as managers: investors and reluctants in a dual role. Health Serv Manage Res. 2004;17:167-176.

58. Shortell SM, Schmittdiel J, Wang MC, et al. An empirical assessment of high performing medical groups: results from a national study. Med Care Res Rev. 2005;62(4):407-434.

59. Casalino L, Gillies RR, Shortell SM, et al. External incentives, information technology and organised processes to improve health care quality of patients with chronic diseases. JAm Med Assoc. 2003;289(4): 434-441.

60. National Co-ordinating Centre for NHS Service Delivery and Organisation. Managing Change and Role Enactment in the Professionalised Organisation. London, UK: NCCSDO; 2006.

61. Castro PJ, Dorgan S, Richardson B. A healthier health care system for the United Kingdom. The Mckinsey Qurterly, February 2008.

62. Molinari C, Alexander J, Morlock L, et al. Does the hospital board need a doctor? The influence of physician board participation on hospital financial performance. Med Care. 1995;33(2):170-185.

63. Ford-Eickhoff K, Plowman DA, McDaniel RR. Hospital boards and hospital strategic focus: the impact of board involvement in strategic decision making. Management department faculty publications; 2011. Available from: http://digitalcommons.unl.edu/managementfacpub/67/. Accessed March 21, 2015.
64. Academy of Medical Royal Colleges. Enhancing engagement in clinical leadership, 2007. Available from: http://www.institute. nhs.uk/building_capability/enhancing_engagement/enhancing _ engagement_in_medical_leadership.html. Accessed January 12, 2014.

65. Goodall AH. Physician-leaders and hospital performance: is there an association? Soc Sci Med. 2011;73:535-539.

66. Goldstein SM, Ward PT. Performance effects of physicians' involvement in hospital strategic decisions. J Serv Res. 2004;6:361-372.

67. Keroack MA, Youngber BJ, Cerese JL, et al. Organizational factors associated with high performance in quality and safety in academic medical centers. Acad Med. 2007;82(12):1178-1186.

68. Baker GR. The roles of leaders in high-performing healthcare systems; 2011. Available from: http://www.kingsfund.org.uk/sites/ files/kf/roles-of-leaders-high-performing-health-care-systemsross-baker-kings-fund-may-2011.pdf. Accessed January 17, 2015.

69. Hartley J, Martin J, Benington J. Leadership in Healthcare: A Review of Literature for Healthcare Professionals, Managers and Researchers. Warwick, UK: Institute of Governance and Public Management (IGPM); 2008.

70. Darzi A. High quality care for all: NHS next stage review final report; 2007. Available from: https://www.gov.uk/government/uploads/system/ uploads/attachment_data/file/228836/7432.pdf. Accessed April 7, 2015.

71. Mountford J, Webb C. When clinicians lead; 2009. Available from: http://www.mckinsey.com/insights/health_systems_and_services/ when_clinicians_lead. Accessed April 7, 2015.

72. Bohmer R. Leadership with a small 'l'. Br Med J. 2010;340:c.483.

73. Health Policy and Economic Research Unit. BMA Doctors'Perspectives on Clinical Leadership. London, UK: BMA; 2012.

74. Degeling P, Kennedy J, Hill M. Mediating the cultural boundaries between medicine, nursing and management - the central challenge in hospital reform. Health Serv Manage Res. 2001;14: $36-48$.

75. Spurgeon P, Clark J, Ham C. Medical Leadership: From the Dark Side to Centre Stage. London, UK: Radcliffe Publishing; 2011.

76. Lubit $\mathrm{R}$. The long-term organizational impact of destructively narcissistic managers. Acad Manage Exec. 2002;16(1):127-138.

77. Mintzberg H. Structures in Fives: Designing Effective Organizations. Englewood Cliffs, NY: Prentice Hall/Pearson Education; 1992.

78. Edmonstone J. The development of strategic clinical leaders in the National Health Service in Scotland. Leader Health Serv. 2011;24(4):337-353.

79. Swanwick T, McKimm J. Clinical leadership development requires system-wide interventions, not just courses. Clin Teach. 2012; 9:89-93.

80. Ham C, editor. Enhancing Engagement in Medical Leadership: A Rapid Survey of International Experience. Coventry, UK: NHS Institute for Innovation and Improvement, Academy of Medical Royal Colleges and Health Services Management Centre, University of Birmingham; 2008.

81. Frank JR, editor. The CanMEDS Physician Competency Framework. Better Standards. Better care. Ottowa, ON: The Royal College of Physicians and Surgeons; 2005.

82. Day DV, Fleenor JW, Atwater LE, et al. Advances in leader and leadership development: a review of 25 years of research and theory. Leader $Q$. 2014;25:63-82.

83. NHS Institute for Innovation and Improvement. Available from: http:// nhsleadershipframework.rightmanagement.co.uk/assets/x/50130. Accessed August 5, 2015.

84. Alban-Metcalfe J, Alimo-Metcalfe B. Engaging leadership part 1: competencies are like Brighton Pier. Int J Leader Publ Serv. 2009;5(1): $10-18$.

85. NHS Leadership Academy. Largest-ever NHS development programme launches today. Available from: http://www. leadershipacademy.nhs.uk/about/media/news/programmes/largestever-nhs-development-programme-launches-today/. Accesses April 28, 2015. 
86. NHS Leadership Academy. Available from: http://www.leader shipacademy.nhs.uk/resources/. Accessed July 13, 2015.

87. Bolden R, Gosling J. Leadership competencies: time to change the tune? Leadership. 2006;2:147-163.

88. Goleman D, Boyatzis R, McKee A. Primal Leadership: Realizing the Power of Emotional Intelligence. Boston, MA: Harvard Business School Press; 2002.

89. Edmonstone J. The challenge of capability in leadership development. Br J Health Manage. 2011;17(12):572-578.

90. McKimm J, Swanwick T. Leadership development for clinicians: what are we trying to achieve? Clin Teach. 2011;8:181-185.

91. Spehar I, Frich JC, Kjekshus LE. Clinicians' experience of becoming a clinical manager: a qualitative study. BMC Health Serv Res. 2012;12:421.

92. Warren O, Humphris P, Bicknell C. Prepare to lead: reflections on the first year of a leadership development mentoring programme for specialist and GP registrars in London. Int J Clin Leader. 2009;16: 149-155.

93. Hawken J, Lee-Wright R, Walsh S. It Takes Two: Encouraging the Development of Leadership Skills in Junior Doctors and Management Trainees. London, UK: BMJ Careers. Available from: http://careers.bmj. com/careers/advice/view-article.html?id=20009302. Accessed April 28, 2015.

94. Klaber RE, Lee J. Clinical leadership and management in the NHS paired learning. $J$ R Soc Med. 2011;104:436.

95. Kelly N. Working better together: joint leadership development for doctors and managers. BMJ Qual Improv Rep. 2014;3(1). doi: 10.1136/ bmjquality.u204792.w2027.

96. Nicol E. Capitalising on leadership fellowships for clinicians in the NHS. Clin Med. 2011;11(2):125-127.

97. Faculty of Medical Leadership and Management. Available from: https://www.fmlm.ac.uk/professional-development/national-medicaldirectors-clinical-fellow-scheme. Accessed April 29, 2015.

98. Bagnall P. Facilitators and barriers to leadership and quality improvement, 2011. Available from: http://www.kingsfund.org.uk/document. rm?id=9547. Accessed April 30, 2015.

99. Stoll L, Swanwick T, Foster-Turner J, et al. Leadership development for junior doctors: what can we learn from 'Darzi' fellowships in clinical leadership? Int J Leader Publ Serv. 2011;12:273-286.
100. London Leadership Academy. Fellowships in Clinical Leadership (Darzi Fellowships). Available from: http://www.londonleadingforhealth.nhs. uk/programmes/fellowships-clinical-leadership-darzi-fellowships. Accessed May 8, 2015.

101. The Commonwealth Fund. Available from: http://www.commonwealthfund.org/grants-and-fellowships/fellowships/harkness-fellowships. Accessed April 30, 2015.

102. Gamble J, Vaux E. Learning leadership skills in practice through quality improvement. Clin Med. 2014;14(1):12-15.

103. National Advisory Group on the Safety of Patients in England. A promise to learn-A commitment to act; 2013. Available from: https:// www.gov.uk/government/uploads/system/uploads/attachment_data/ file/226703/Berwick_Report.pdf. Accessed April 30, 2015.

104. Swanwick T, McKimm J. Faculty development for leadership and management In: Steinert Y, editor. Faculty Development for the Health Professions. New York, NY: Springer; 2014.

105. Bolden R. What is leadership development? Purpose and practice. Leadership south west research report 2 [Online], 2005. Available from: https://ore. exeter.ac.uk/repository/bitstream/handle/10036/77193/What_is_Leadership_Development.pdf?sequence=1. Accessed April 10, 2015.

106. Edmonstone JD. Whither the elephant?: the continuing development of clinical leadership in the UK National Health Services. Int J Health Plann Manage. 2014;29:280-291.

107. Baker GR, Denis J-L. Medical leadership in health care systems: from professional authority to organizational leadership. Publ Money Manag. 2011;31(5):355-362.

108. Alimo-Metcalfe B, Alban Metcalfe J. Engaging Leadership: Creating Oragnisations That Maximize the Potential of Their People. London, UK: Chartered Institute of Personnel and Development; 2008.

109. The King's Fund. Leadership and Engagement in the NHS - Together We Can. London, UK: The King's Fund; 2012. Available from: http:// www.kingsfund.org.uk/sites/files/kf/field/field_publication_file/ leadership-for-engagement-improvement-nhs-final-review2012.pdf. Accessed April 29, 2015.
Journal of Healthcare Leadership

\section{Publish your work in this journal}

The Journal of Healthcare Leadership is an international, peer-reviewed, open access journal focusing on leadership for the health profession. The journal is committed to the rapid publication of research focusing on but not limited to: Healthcare policy and law; Theoretical and practical aspects healthcare delivery; Interactions between healthcare and society and evidence-based practices;

\section{Dovepress}

Interdisciplinary decision-making; Philosophical and ethical issues; Hazard management; Research and opinion for health leadership; Leadership assessment. The manuscript management system is completely online and includes a very quick and fair peer-review system. Visit http://www.dovepress.com/ testimonials.php to read real quotes from published authors. 